\title{
ANALISIS RASIO PROFITABILITAS PADA PT. BANK PERKREDITAN RAKYAT CEMPAKA MITRA NAGARI PADANG
}

\author{
Mega Vernida, Doni Marlius \\ Akademi Keuangan dan Perbankan "Pembangunan" (AKBP) Padang \\ $\underline{\text { megafernida16@gmail.com }}$
}

\begin{abstract}
Based on the results of the analysis in the previous chapter, a description of the level of profitability of PT. Cempaka Mitra Nagari Padang Rural Credit Bank during the period 2018-2019 it can be concluded tha t: Return on Assets (ROA) owned by PT. Cempaka Mitra Nagari Padang Rural Credit Bank for 2018-2019 is in an unhealthy position, because it does not meet the BI minimum standard requirements. Return on Equity (ROE) ratio at PT. Cempaka Mitra Nagari Padang Rural Credit Bank for the period 2018-2019 according to unhealthy conditions or can be approved by inefficient banks to obtain net income. Judging from the level of Operational Costs (BOPO) of PT. Cempaka Mitra Nagari Padang Rural Credit Bank in 2018-2019 the bank can manage it well, because it is able to control its operational costs. The level of Net Profit Margin (NPM) in PT. Cempaka Mitra Nagari Padang Rural Credit Bank in the 2018-2019 period changed the increase, meaning that the bank could still ask for a net profit.
\end{abstract}

Keywords: Profitability, ROA, ROE, BOPO and NPM.

\section{PENDAHULUAN}

Keadaan sektor perbankan sebagai subsistem perekonomian suatu negara mempunyai peran penting, bahkan dikehidupan masyarakat modern sekarang sebagian besar masyarakat menjadikan jasa perbankan untuk membantu kegiatan keuangan mereka karena pada dasarnya perbankan bertujuan untuk menunjang pembangunan nasional dan meningkatkan kesejahteraan masyarakat. Oleh karena itu perbankan harus melaksanakan manajemen perbankan menjadi lebih profesional.

Menurut (Fernos, 2017) Bank merupakan lembaga yang berperan sebagai perantara keuangan antara pihak yang mempunyai dana dan pihak yang membutuhkan dana serta lembaga yang berfungsi untuk memperlancar lalu lintas pembayaran. Selain melakukan kegiatan penghimpunan dan penyaluran dana bank juga berusaha mengembangkan berbagai produk dan pelayanan jasa yang lainnya untuk meningkatkan keuntungan bagi bank tersebut.

Perbankan yang baik dapat dilihat dari jumlah keuntungan yang di peroleh setiap tahunnya. Untuk mengetahui keuntungan tersebut dapat dilakukan dengan 
cara melihat laporan keuangan bank. Laporan keuangan bank sangat diperlukan untuk mengetahui bagaimana kondisi keuangan pada suatu bank dan bisa memberikan gambaran tentang kemajuan bank secara keseluruhan. Laporan keuangan disusun dan disajikan dalam bentuk neraca, laporan laba-rugi, laporan perubahan modal dan laporan arus kas. Dengan adanya laporan keuangan ini dapat diketahui bahwa bank tersebut mengalami kemajuan atau malah sebaliknya mengalami kemunduran setiap tahunnya.

Dalam laporan keuangan yang diterbitkan oleh suatu bank, kita harus melakukan analisis terlebih dahulu. Tujuannya agar kita bisa memahami dimana letak kelebihan dan kekurangan pada bank tersebut. Melalui laporan keuangan ini dapat diketahui juga laba yang dihasilkan perusahaan, serta jumlah aktiva, modal dan hutang yang dimiliki oleh perusahaan.

Analisis rasio keuangan adalah proses pengamatan indeks yang berhubungan dengan akuntansi pada laporan keuangan seperti neraca, laporan laba rugi dan laporan arus kas dengan tujuan untuk menilai kinerja keuangan suatu perusahaan. Analisis ini digunakan untuk memberikan gambaran informasi mengenai posisi keuangan dan kinerja perusahaan yang dapat dijadikan sebagai pedoman dalam mengambil keputusan (Antara et al., 2014)

Untuk mengukur kinerja keuangan suatu bank dapat dilakukan dengan menggunakan beberapa rasio keuangan. (Suherti \& Fernos, n.d.) Rasio adalah suatu angka yang menunjukkan hubungan antara suatu unsur dengan unsur lainnya dalam laporan keuangan. Rasio keuangan merupakan alat analisis perusahaan untuk menilai kinerja suatu perusahaan berdasarkan perbandingan data keuangan yang terdapat pada laporan keuangan (neraca, laporan laba rugi, laporan arus kas). Setiap rasio memiliki kegunaan, tujuan dan makna masingmasing. Rasio yang digunakan dalam penulisan Tugas Akhir ini hanya Rasio Profitabilitas. Rasio Profitabilitas merupakan rasio yang digunakan untuk menilai kemampuan perusahaan dalam mencari keuntungan dalam suatu periode tertentu. Rasio ini juga memberikan tingkat efektivitas manajemen dalam mengelola perusahan. Jenis-jenis rasio profitabilitas dipakai untuk memperlihatkan seberapa besar laba atau keuntungan yang diperoleh dari kinerja suatu perusahaan yang memengaruhi catatan atas laporan keuangan yang harus sesuai dengan standar akuntansi keuangan.

Menurut (Yanti \& Afriyeni, 2017) Untuk melihat kemampuan bank dalam memperoleh laba pada periode tertentu maka digunakan rasio profitabilitas. Rasio Profitabilitas menggunakan beberapa rasio keuangan seperti, Return on Asset (ROA), Return on Equity (ROE), Biaya Operasional (BOPO), dan Net Profit Margin (NPM).

Profitabilitas pada bank dapat dikatakan baik apabila bank mampu memenuhi target laba yang telah ditetapkan berdasarkan aktiva atau modal yang ada pada periode tersebut. Apabila pengelolaan keuangannya tidak baik makaakan mengakibatkan terganggunya kinerja perusahaan. Semua pihak yang bersangkutan dalam mengelola keuangan harus mampu melaksanakan tugasnya 
sebaik mungkin supaya pemasukan dan pengeluaran tetap stabil dan perusahaan tidak mengalami kerugian. Dengan tingkat profitabilitas yang tinggi berarti perusahaan akan beroperasi pada tingkat biaya rendah yang akhirnya akan menghasilkan laba yang tinggi. Dengan semua rasio profitabilitas, perbandingan dari sebuah perusahaan dengan perusahaan serupa dapat dinilai dengan pasti. Hanya dengan melakukan perbandingan dapat menilai apakah profitabilitas dari suatu perusahaan baik atau jelek.

Penggunaan rasio profitabilatas dapat dilakukan dengan menggunakan perbandingan antara komponen yang ada pada laporan keuangan terutama pada laporan keuangan neraca dan laporan keuangan laba rugi. Apabila bank mampu mencapai target labanya itu berarti bank berhasil dalam menjalankan misinya, jika sebaliknya perolehan laba tidak mencapai target, maka dapat dikatakan bankgagaldalam menjalankan misinya.

Menurut (Afriyeni \& Fernos, 2018) ROA adalah alat untuk mengetahui tingkat keuntungan yang dihasilkan perusahaan dengan menmanfaatkan semua aset yang dimilikinya. Dengan Return On Asset (ROA) kita bisa menilai apakah perusahaan sudah efektif atau belum dalam memakai aktivanya dalam aktivitas opesasi untuk menghasilkan keuntungan. Semakin baik tingkat ROA maka bank dikatakan baik dalam mengelola aktivanya.

Return on Equity (ROE) mengukur seberapa besar pengambilan yang diperoleh pemegang saham atas modal yang disetorkannya pada bank yang bersangkutan. Semakin tinggi rasio ini maka akan semakin baik, karena memberikan tingkat pengembalian yang lebih besar pada pemegang saham.

Menurut (Afriyeni \& Fernos, 2018) Rasio Biaya Operasional (BOPO) adalah rasio yang membandingkan beban operasional dengan pendapatan operasional, dengan tujuan untuk mengetahui seberapa besar kemampuan perusahaan dalam mengelola beban operasional agar tidak meningkat. Semakin besar nilai BOPO, maka semakin tidak efisien manajemen bank dalam mengelola beban operasionalnya. BOPO yang cendrung meningkat terus mengindikasikan manajemen bank tidak mampu memaksimalkan pendapatan lebih besar demi mengcover biaya-biaya operasionalnya. Rasio BOPO yang bagus adalah rasio BOPO yang semakin kecil. Rasio BOPO yang turun artinya perusahaan mampu menurunkan beban operasional dan memaksimalkan pendapatan.

Net Profit Margin (NPM) adalah rasio yang digunakan untuk mengukur persentase laba bersih pada suatu perusahaan terhadap penjualan bersihnya. NPM digunakan untuk mengukur efisiensi pengelolaan perusahaan dan memperkirakan profitabilitas masa depan perusahaan.

Berdasarkan Latar Belakang yang diuraikan diatas, maka penulis tertarik untuk mengambil judul "Analisis Rasio Profitabilitas Pada Pt. Bank Perkreditan Rakyat Cempaka Mitra Nagari Padang."

PT. Bank Perkreditan Rakyat Cempaka Mitra Nagari Padang merupakan salah satu bank yang ada dikota padang, terletak di Jl. Andalas No. 2G Simpang 
Haru, Padang. Untuk mencapai keuntungan yang maksimal dimasa yang akan datang, Bank Perkreditan Rakyat Cempaka Mitra Nagari ini harus memperhatikan tingkat profitabilitas yang dimilikinya agar dapat mencapai suatu keuntungan yang lebih dimasa mendatang. Salah satu indikator yang dipakai untuk melihat keberhasilan atau kegagalan BPR dalam mencapai tujuan tersebut yaitu laporan kinerja keuangan bank yang telah dicapai. Berikut perkembangan Rasio Profitabilitas PT. Bank Perkreditan Rakyat Cempka Mitra Nagari Padang tahun 2018 hingga 2019:

\section{Tabel 1}

Perkembangan Rasio Profitabilitas

Tahun 2018-2019

\begin{tabular}{lcc}
\hline \multicolumn{1}{c}{ Indikator } & $\mathbf{2 0 1 8}$ & $\mathbf{2 0 1 9}$ \\
\hline Return On Asset & $1,02 \%$ & $0,78 \%$ \\
Return On Equity & $0,54 \%$ & $0,44 \%$ \\
Biaya Operasional & $91,90 \%$ & $93,43 \%$ \\
Net Profit Margin & $6,87 \%$ & $5,62 \%$ \\
\hline
\end{tabular}

Sumber : PT.BPR Cempaka Mitra Nagari Padang, Data diolah

Berdasarkan tabel diatas secara umum dapat dilihat bahwa laporan keuangan PT. BPR Cempaka Mitra Nagari Padang tahun 2018-2019 pada Rasio Profitabilitas mengalami penurunan. Dimana dapat dilihat pada keadaan ROA tahun 2018 sebesar 1,02\% turun menjadi 0,78\% ditahun 2019. Keadaan ROE tahun 2018 sebesar 0,54\% juga turun menjadi 0,44\%. Biaya Operasional PT. BPR Cempaka Mitra Nagari Padang tahun 2018 sebesar 91,90\% mengalami peningkatan ditahun 2019 sebesar 93,43\%. Sedangkan posisi NPM yang diperoleh PT. BPR Cempaka Mitra Nagari Padang tahun 2018 sebesar 6,87\% turun menjadi $5,62 \%$ di tahun 2019. Berdasarkan uraian tersebut, maka tujuan penelitian ini yaitu untuk mengetahui bagaimana rasio profitabilitas yang diukur dari Return on Asset (ROA), Return on Equity (ROE), Biaya Operasional (BOPO), serta Net ProfitMargin (NPM) pada PT. Bank Perkreditan Rakyat Cempaka Mitra Nagari Padang dalam periode 2018-2019

\section{METODE PENELITIAN}

\section{Metode Pengumpulan Data}

Untuk keperluan penelitian ini, pengumpulan data dilakukan dengan dua cara yaitu :

a. Riset Lapangan (Field Research)

Yaitu suatu metode peninjauan langsung ke objek penelitian yang dipilih untuk meneliti hasil data sekunder. Penelitian langsung kelapangan ini dapat membantu penulis melengkapi data yang diperlukan. Adapun cara riset lapangan ini yaitu dengan mewawancarai secara langsung pihak-pihak yang relevan dengan masalah penelitian. 
b. Riset Perpustakaan ( Library Research)

Yaitu penelitian yang dilakukan ke perpustakaan berupa buku-buku ilmiah serta tulisanyang berkaitan dengan pembahasan yang dilakukan.

\section{Metode Analisis Data}

Dalam menganalisa data, penulis menggunakan metode analisa data kualitatif dan kuantitatif. Dimana metode kualitatif menggambarkan dan menjelaskan data yang diteliti selama penelitian berlangsung, sedangkan metode kuantitatif menganalisis perhitungan tingkat Profitabilitas PT.BPR Cempaka Mitra Nagari Padang.

\section{HASIL DAN PEMBAHASAN}

Berdasarkan data keuangan PT. BPR Cempaka Mitra Nagari Padang yang telah diperoleh, selanjutnya akan dilakukan perhitungan tentang rasio keuangan dengan 4 indikator sebagai berikut:

1. ROA (Return on Asset)

Menurut (Afriyeni \& Fernos, 2018) ROA adalah alat untuk mengetahui tingkat keuntungan yang dihasilkan perusahaan dengan menmanfaatkan semua aset yang dimilikinya. Dengan Return On Asset (ROA) kita bisa menilai apakah perusahaan sudah efektif atau belum dalam memakai aktivanya dalam aktivitas opesasi untuk menghasilkan keuntungan. Semakin baik tingkat ROA maka bank dikatakan baik dalam mengelola aktivanya. Sesuai SK Direksi BI No. 30/12/KEP/DIR/ tanggal 30 April 1997 tentang penilaian tingkat kesehatan Bank Perkreditan Rakyat pada tingkat ROA yaitu dengan score minimal 1,22\% dikatakan baik. Berdasarkan data yang didapat ROA Bank Perkreditan Rakyat Cempaka Mitra Nagari Padang pada Tahun 2018-2019 ditunjukkan pada tabel.2 dibawah ini:

\section{Tabel.2}

Perhitungan ROA BPR Cempaka Mitra Nagari Padang

Tahun 2018-2019

(Dalam Ribuan Rupiah)

\begin{tabular}{lrc}
\hline Komponen & 2018 & 2019 \\
\hline 1. ROA &
\end{tabular}

a. Laba Bersih Sebelum Pajak

94.922

76.569

b. Total Aktiva

9.326 .617

9.752 .202

Sumber : Data Olahan

Dengan Formula :

$$
R O A=\frac{\text { LabaSebelumPajak }}{\text { TotalAktiva }} \times 100 \%
$$


a. Perhitungan ROA tahun 2018

$$
R O A=\frac{R p \cdot 94.922}{R p \cdot 9.326 .617} \times 100 \%=1,02 \%
$$

Artinya kemampuan Bank Perkreditan Rakyat Cempaka Mitra Nagari Padang mendapatkan laba dari sejumlah aktiva yang terpakai dengan nilai ROA tahun 2018 sebesar 1,02\% dengan arti bahwa setiap Rp. 100 aktiva yang dimilikinya, bank hanya mampu mendapatkan laba bersih sebelum pajak senilai Rp. 1,02. Artinya Bank Perkreditan Rakyat Cempaka Mitra Nagari Padang dapat dikatakan tidak baik, karena semakin rendah nilai ROA, maka bank tersebut kurang efisien mengelola aktivanya untuk menghasilkan keuntungan sebelum pajak.

b. Perhitungan ROA tahun 2019

$$
R O A=\frac{R p \cdot 76 \cdot 569}{R p \cdot 9.752 .202} \times 100 \%=0,78 \%
$$

Artinya kemampuan Bank Perkreditan Rakyat Cempaka Mitra Nagari Padang mendapatkan laba dari sejumlah aktiva yang terpakai dengan nilai ROA tahun 2019 sebesar $0,78 \%$ dengan arti bahwa setiap Rp. 100 aktiva yang dimilikinya, bank hanya mampu mendapatkan laba bersih sebelum pajak senilai Rp. 0,78. Artinya Bank Perkreditan Rakyat Cempaka Mitra Nagari Padang dapat dikatakan tidak baik, karena semakin rendah nilai ROA, maka bank tersebut tidak efisien mengelola aktivanya untuk menghasilkan keuntungan sebelum pajak.

\section{ROE (Return on Equity)}

Return on Equity (ROE) mengukur seberapa besar pengambilan yang diperoleh pemegang saham atas modal yang disetorkannya pada bank yang bersangkutan. Semakin tinggi rasio ini maka akan semakin baik, karena memberikan tingkat pengembalian yang lebih besar pada pemegang saham. Menurut SK Direksi BI No. 30/12/KEP/DIR tanggal 30 April 1997 tentang penilaian tingkat kesehatan BPR pada tingkat ROE yaitu lebih dari $18 \%$ (Baik). Berdasarkan data yang diperoleh ROE pada Bank Perkreditan Rakyat Cempaka Mitra Nagari Padang tahun 2018-2019 dapat dilihat pada tabel.3 di bawah ini.

Tabel.3

Perkembangan ROE BPR Cempaka Mitra Nagari Padang

Tahun 2018-2019

(Dalam Ribuan Rupiah)

\begin{tabular}{lcr}
\hline \multicolumn{1}{c}{ Komponen } & $\mathbf{2 0 1 8}$ & $\mathbf{2 0 1 9}$ \\
\hline 2. ROE & 80.588 & 65.683 \\
a. Laba Bersih Setelah Pajak & & \\
b. Modal Sendiri & 15.000 .000 & 15.000 .000 \\
\hline
\end{tabular}

Sumber : Data Olahan 
Dengan Formula :

a. Perhitungan ROE tahun 2018

$$
R O E=\frac{\text { LabaSetelahPajak }}{\text { Modal Sendiri }} \times 100 \%
$$

$$
R O E=\frac{R p \cdot 80 \cdot 588}{R p \cdot 15 \cdot 000 \cdot 000} \times 100 \%=0,54 \%
$$

Artinya kemampuan Bank Perkreditan Rakyat Cempaka Mitra Nagari Padang dalam memperoleh laba dari modal sendiri sangat rendah yaitu sebesar $0,54 \%$, yang berarti bahwa semakin rendah ROE pada bank menunjukkan bank tersebut kurang efisien untuk memperoleh laba bersih setelah pajak.

b. Perhitungan ROE tahun 2019

$$
R O E=\frac{R p \cdot 65 \cdot 683}{R p \cdot 15 \cdot 000 \cdot 000} \times 100 \%=0,44 \%
$$

Artinya kemampuan Bank Perkreditan Rakyat Cempaka Mitra Nagari Padang untuk mendapatkan keuntungan dari modal sendiri bernilai $0,44 \%$, hal tersebut menunjukkan bank kurang efisien dalam memperoleh laba setelah pajak.

3. BOPO (Biaya Operasional)

Menurut (Afriyeni \& Fernos, 2018) Rasio Biaya Operasional (BOPO) adalah rasio yang membandingkan beban operasional dengan pendapatan operasional, dengan tujuan untuk mengetahui seberapa besar kemampuan perusahaan dalam mengelola beban operasional agar tidak meningkat. Semakin besar nilai BOPO, maka semakin tidak efisien manajemen bank dalam mengelola beban operasionalnya. BOPO yang cendrung meningkat terus mengindikasikan manajemen bank tidak mampu memaksimalkan pendapatan lebih besar demi mengcover biaya-biaya operasionalnya.Rasio BOPO yang bagus adalah rasio BOPO yang semakin kecil. Rasio BOPO yang turun artinya perusahaan mampu menurunkan beban operasional dan memaksimalkan pendapatan.

Berdasarkan SK Direksi BI No. 30/12/KEP/DIR tanggal 30 April 1997 tentang penilaian tingkat kesehatan BPR pada tingkat BOPO yaitu dengan Maksimal 93,52\%, karena jika rasio BOPO melebihi angka yang telah ditetapkan bahkan mendekati 100\% maka bank tersebut dapat dikatakan tidak efisien menjalankan kegiatan operasionalnya. Berdasarkan data yang didapat BOPO pada Bank Perkreditan Rakyat Cempaka Mitra Nagari Padang dari tahun 2018-2019 ditunjukkan pada tabel.4 di bawah ini. 
Tabel.4

Perkembangan BOPO BPR Cempaka Mitra Nagari Padang

Tahun 2018-2019

(Dalam Ribuan Rupiah)

\begin{tabular}{lrr}
\hline \multicolumn{1}{c}{ Komponen } & $\mathbf{2 0 1 8}$ & $\mathbf{2 0 1 9}$ \\
\hline 1. BOPO & & \\
a. Beban Operasional & 30.867 & 3.600 \\
- Beban Penyisihan Kerugian & & \\
AssetProduktif & 6.737 & 4.672 \\
-Beban Pemasaran & 990.590 & 1.025 .630 \\
- Beban Adm \& Umum & 49.539 & 57.582 \\
-Beban Operasional lainnya & 1.077 .733 & 1.091 .484 \\
Jumlah Beban Oprasional & & \\
b. Pendapatan Operasional & 1.050 .400 & 1.081 .650 \\
-Jumlah Pendapatan Bunga Bersih & 122.285 & 86.603 \\
-Pendapatan Operasional Lainnya & 1.172 .685 & 1.168 .253 \\
Jumlah Pendapatan Operasional & & \\
\hline
\end{tabular}

Sumber : Data Olahan

Dengan Formula :

$$
\text { BOPO }=\frac{\text { Total Beban Operasional }}{\text { Total Pendapatan Operasional }} \times 100 \%
$$

Beban Operasional $=$ Beban Penyisihan Kerugian Asset Produktif + Beban Pemasaran + Beban Adm \& Umum + Beban Operasional Lainnya

Pendapatan Operasional $=$ Jumlah Pendapatan Bunga Bersih + Pendapatan

a. Perhitungan BOPO tahun 2018 Operasional Lainnya

$$
B O P O=\frac{R p \cdot 1 \cdot 077 \cdot 733}{R p \cdot 1 \cdot 172 \cdot 685} \times 100 \%=91,90 \%
$$

Artinya kemampuan Bank Perkreditan Rakyat Cempaka Mitra Nagari Padang dalam melaksanakan kegiatan operasionalnyadikatakan efisien karena tingkat BOPO yang dicapai adalah $91.90 \%$, berada dibawah batas maksimal $(93,52 \%)$ dimana jika semakin rendah tingkat BOPO pada bank maka semakin efisien bank mengendalikan biaya operasionalnya.

b. Perhitungan BOPO tahun 2019

$$
B O P O=\frac{R p \cdot 1 \cdot 091 \cdot 484}{R p \cdot 1 \cdot 168 \cdot 253} \times 100 \%=93,43 \%
$$


Artinya kemampuan Bank Perkreditan Rakyat Cempaka Mitra Nagari Padang dalam melaksanakan kegiatan operasionalnya dikatakan efisien karena tingkat BOPO yang dicapai adalah 93,43\%, berada dibawah batas maksimal $(93,52 \%)$ dimana jika semakin rendah tingkat BOPO pada bank maka semakin efisien bank mengendalikan biaya operasionalnya.

4. NPM (Net Profit Margin)

Net Profit Margin (NPM) adalah rasio yang digunakan untuk mengukur persentase laba bersih pada suatu perusahaan terhadap penjualan bersihnya. NPM digunakan untuk mengukur efisiensi pengelolaan perusahaan dan memperkirakan profitabilitas masa depan perusahaan.

Berdasarkan SK Direksi BI No. 30/12/KEP/DIR tanggal 30 April 1997 tentangpenilaian tingkat kesehatan BPR pada rasio NPM dikatakan baik jika lebih dari 5\%. Semakin tinggi rasio ini berarti kemampuan bank menghasilkan laba semakin efisien.Berdasarkan data yang diperoleh NPM pada Bank Perkreditan Rakyat Cempaka Mitra Nagari Padang dari tahun 2018-2019 ditunjukkan pada tabel.5 dibawah ini.

Tabel.5

Perkembangan NPM BPR Cempaka Mitra Nagari Padang Tahun 2018-2019

(Dalam Ribuan Rupiah)

\begin{tabular}{|c|c|c|}
\hline Komponen & 2018 & 2019 \\
\hline 1. NPM & & \\
\hline a. Laba Bersih Setelah Pajak & 80.588 & 65.683 \\
\hline b. Pendapatan Operasional & & \\
\hline -Jumlah Pendapatan Bunga Bersih & 1.050 .400 & 1.081 .650 \\
\hline -Pendapatan Operasional Lainnya & 122.285 & 86.603 \\
\hline Jumlah Pendapatan Operasional & 1.172 .685 & 1.168 .253 \\
\hline
\end{tabular}

Sumber : Data Olahan

Dengan Formula :

$$
N P M=\frac{\text { Laba Bersih Setelah Pajak }}{\text { Total Pendapatan Operasional }} \times 100 \%
$$

Pendapatan Operasional = Jumlah Pendapatan Bunga Bersih + Pendapatan Operasional Lainnya

a. Perhitungan NPM tahun 2018

$$
N P M=\frac{R p \cdot 80.588}{R p \cdot 1 \cdot 172.685} \times 100 \%=6,87 \%
$$

Artinya kemampuan Bank Perkreditan Rakyat Cempaka Mitra Nagari Padang dalam memperoleh laba bersih jika dilihat dari NPM 
yang dimilikinya sebesar $6,87 \%$. Hal ini menunjukkan bahwa bank sudah efisien dalam menghasilkan laba. Karna tingkat NPM berada di atas batas minimal (5\%), dimana jika semakin tinggi tingkat NPM pada bank maka dikatakan bank semakin efisien dalam mengukur kemampuan pendapatan operasionalnya untuk menghasilkan laba.

b. Perhitungan NPM tahun 2019

$$
N P M=\frac{R p \cdot 65 \cdot 683}{R p \cdot 1 \cdot 168 \cdot 253} \times 100 \%=5,62 \%
$$

Artinya kemampuan Bank Perkreditan Rakyat Cempaka Mitra Nagari Padang memperoleh laba bersih cukup baik, dimana dapat dilihat dengan tingkat NPM bank sebesar 5,62\%, semakin tinggi NPM maka bank semakin efisien dalam mengukur kemampuan pendapatan operasionalnya untuk menghasilkan keuntungan.

Berdasarkan analisis yang telah dilakukan, kemampuan BPR Cempaka Mitra Nagari Padang mendapatkan laba dari sejumlah aktiva yang terpakai dengan nilai ROA tahun 2018 sebesar 1,02\% turun menjadi 0,78\% ditahun 2019. Keadaan ROE tahun 2018 sebesar 0,54\% juga turun menjadi 0,44\%. Biaya Operasional PT. BPR Cempaka Mitra Nagari Padang tahun 2018 sebesar 91,90\% mengalami peningkatan ditahun 2019 sebesar 93,43\%. Sedangkan posisi NPM yang diperoleh PT. BPR Cempaka Mitra Nagari Padang tahun 2018 sebesar 6,87\% turun menjadi 5,62\% di tahun 2019.

\section{SIMPULAN}

Berdasarkan hasil analisis pada bab sebelumnya, gambaran tingkat profitabilitas PT. Bank Perkreditan Rakyat Cempaka Mitra Nagari Padang selama periode tahun 2018-2019 dapat disimpulkan bahwa :

1) Return on Asset (ROA) yang dimiliki PT. Bank Perkreditan Rakyat Cempaka Mitra Nagari Padang untuk tahun 2018-2019 berada pada posisi tidak sehat, karena tidak memenuhi ketentuan standar minimum BI.

2) Pada rasio Return on Equity (ROE) pada PT. Bank Perkreditan Rakyat Cempaka Mitra Nagari Padang untuk periode 2018-2019 berada dalam kondisi tidak sehat atau dapat dikatakan bank tidak efisien memperoleh laba bersihnya.

3) Dilihat dari tingkat Biaya Operasional (BOPO) PT. Bank Perkreditan Rakyat Cempaka Mitra Nagari Padang tahun 2018-2019 bank dapat beroperasi dengan baik, karena mampu mengendalikan biaya operasionalnya.

4) Tingkat Net Profit Margin (NPM) yang ada pada PT. Bank Perkreditan Rakyat Cempaka Mitra Nagari Padang periode 2018-2019 mengalami kenaikan, itu berarti bank masih dapat dikatakan baik memperoleh laba bersihnya. 


\section{UCAPAN TERIMA KASIH}

Penulis ucapkan terima kasih kepada Pimpinan PT. BPR Cempaka Mitra Nagari Padang yang telah mengizinkan penulis dalam memperoleh informasi beserta pengambilan data. Serta semua Pihak yang telah memberikan dukungan dan bantuannya dalam penyelesaian penelitian ini.

\section{DAFTAR PUSTAKA}

Afriyeni, A., \& Fernos, J. (2018). Analisis Faktor-Faktor Penentu Kinerja Profitabilitas Bank Perkreditan Rakyat (Bpr) Konvensional Di Sumatera Barat. Jurnal Benefita, 3(3), 325. https://doi.org/10.22216/jbe.v3i3.3623

Antara, S., Sepang, J., \& Saerang, I. S. (2014). Analisis Rasio Likuiditas, Aktivitas, Dan Profitabilitas Terhadap Return Saham Perusahaan Wholesale Yang Terdaftar Di Bursa Efek Indonesia. Jurnal Riset Ekonomi, Manajemen, Bisnis Dan Akuntansi, 2(3), 902-911.

Badria, M., \& Marlius, D. (2019). Analisis Rasio Likuiditas Pada PT. Bank Perkreditan Rakyat (BPR) Lengayang. https://doi.org/10.31219/osf.io/esvb7

Budiasih, Y. (2012). Struktur Organisasi, Desain Kerja, Budaya Organisasi dan Pengaruhnya Terhadap Produktivitas Karyawan. Jurnal Liquidity, 1(2), 99-105.

Fernos, J. (2017). Analisis Rasio Profitabilitas Untuk Mengukur Kinerja Pada PT. Bank Pembangunan Daerah Provinsi Sumatera Barat. Jurnal Pundi, 1(2), 107118. https://doi.org/10.31575/jp.v1i2.25

Fitri, H. Y., \& Marlius, D. (2019). Analisis Rasio Likuiditas Pada PT. Bank Perkreditan Rakyat (BPR) Nagari Kasang. https://doi.org/10.31219/osf.io/bcs73

Gammahendra, F., \& Dkk. (2014). Pengaruh Struktur Organisasi Terhadap Efektivitas Organisasi. Jurnal Administrasi Bisnis (JAB), 7(2), 1-10.

Mustika, S., \& Marlius, D. (2019). Analisa Tingkat Kesehatan Keuangan PT. Bank Perkreditan Rakyat (BPR) Batang Palangki. https://doi.org/10.31219/osf.io/wupyh

Putri, Y. A., \& Marlius, D. (2018). Analisis Tingkat Kesehatan Bank Pada PT. Bank Perkreditan Rakyat (BPR) Jorong Kampuang Tangah Pariaman Cabang Padang. https://doi.org/10.31227/osf.io/r98pv

Sanjaya, A. R., \& Marlius, D. (2017). Peranan Laporan Keuangan Dalam Kebijaksanaan Pemberian Kredit Kepada Calon Nasabah Pada Pt. Bpr Batang Kapas. Junal Akuntansi Keungan, 12.

Sari, Y. P., \& Marlius, D. (2019). Analisis Rasio Profitabilitas Pada PT. Bank Negara Indonesia Syariah. https://doi.org/10.31219/osf.io/94bwq

Suherti, E., \& Fernos, J. (n.d.). Analisa rasio terhadap laporan keuangan pada pt. bank pembangunan daerah sumatera barat. Jurnal Ekonomi Dan Bisnis, 1-15.

Yanti, V. W., \& Afriyeni. (2017). Analisis Rasio Profitabilitas Pada Pt Bank Perkreditan Rakyat (BPR) Cempaka Mitra Nagari Padang. 1-12. 